Artikel Penelitian

\title{
PROFIL KASUS AUTOPSI PADA ANAK DI PROVINSI RIAU PERIODE TAHUN 2010-2014
}

\author{
Mohammad Tegar Indrayana ${ }^{1}$, Dedi Afandi ${ }^{1}$, Stella Putri Wanda ${ }^{2}$, \\ Popi Novia ${ }^{2}$, Satrio Mandala Tinardy ${ }^{2}$
}

\begin{abstract}
Abstrak
Autopsi pada anak memiliki peranan penting guna mengetahui penyebab kematian tidak wajar pada anak. Penelitian ini bertujuan untuk mengetahui profil kasus autopsi pada anak di Provinsi Riau periode tahun 2010-2014. Data diperoleh dari Visum et Repertum jenazah milik Biddokkes Polda Riau yang dianggap dapat mewakilkan gambaran se-Provinsi Riau. Hasil penelitian didapatkan angka autopsi pada anak di Provinsi Riau periode tahun 2010-2014 berjumlah 15 kasus. Karakteristik korban anak didominasi anak laki-laki $(66,7 \%)$ berumur 0-5 tahun (46,7\%). Didapatkan 5 kasus kekerasan tumpul, 3 kasus kekerasan tajam dan 7 kasus tidak dapat digolongkan jenis kekerasannya. Jenis luka akibat kekerasan tajam didominasi oleh luka sayat $(66,7 \%)$ dengan lokasi luka tersering di leher (100\%) sedangkan jenis luka akibat kekerasan tumpul didominasi oleh luka memar (60\%) dengan lokasi luka tersering di kepala (80\%). Seluruh kasus merupakan kematian tidak wajar dengan kasus terbanyak adalah dugaan pembunuhan (60\%). Polsek Kabupaten Kampar merupakan asal polsek tersering (40\%).
\end{abstract}

Kata Kunci: kekerasan pada anak, profil autopsi anak

\section{Abstract}

Autopsy is an important procedure to detecting cause of death in child unnatural death cases. This study aims to describe the profile of child autopsy in Riau Province, Indonesia 2010-2014. Data was obtained from medicolegal autopsy reports that belongs to Riau Regional Police on Medicine and Health. Data is assumed could covered Riau Province child autopsy insidences. There were 15 child medicolegal autopsies recorded between 2010 and 2014 with boy (66,7\%) aged 0 to 5 years old $(46,7 \%)$ were dominant victims. Of the 15 child medicolegal autopsies, 5 cases were blunt force violence, 3 cases were sharp force violence, and 7 were uncategorized. Incised wound $(66,7 \%)$ was lead type of wounds on sharp force violence which localized on neck (100\%). Contusions (60\%) was lead type of wounds on blunt force violence which often localized on head (80\%). Our study highlights that homicide was the predominant manner of death (60\%) and found that Kampar Regency was frequently requested for medicolegal autopsies reports.

Keywords: child abuse autopsy, child autopsy profile

Afiliasi Penulis: 1. Departemen Forensik dan Medikolegal Fakultas Kedokteran Universitas Riau/ RSUD Arifin Achmad; 2. Program Studi Pendidikan Dokter, Fakultas Kedokteran Universitas Riau. Korespondensi : Mohammad Tegar Indrayana, Departemen Forensik dan Medikolegal Fakultas Kedokteran Universitas Riau/ RSUD Arifin Achmad, JI Diponegoro No.1 Pekanbaru 28133. Email: tegar.indrayana@lecturer.unri.ac.id, Telp\HP: 08127601246. 


\section{PENDAHULUAN}

Autopsi didefinisikan sebagai pemeriksaan tubuh mayat yang terdiri dari pemeriksaan bagian luar dan dalam yang bertujuan untuk menentukan identitas seseorang, memperkirakan saat kematian, menentukan cara kematian, serta menerangkan penyebab dari kematian sehingga mengetahui hubungan antara penyebab serta kelainan yang timbul. ${ }^{1}$ Autopsi dapat dilakukan dalam berbagai usia, tergantung dari kasusnya. Salah satu autopsi yang dilakukan adalah autopsi pada anak. Autopsi pada anak memiliki peranan penting guna mengetahui penyebab kematian pada anak. Terdapat beberapa penyebab kematian pada anak, diantaranya adalah kasus kematian disebabkan penyakit, kematian tidak di sengaja (accidental), pembunuhan (homicide), dan bunuh diri (suicide).

Kekerasan merupakan fenomena yang masih sering terjadi di dunia pada saat ini baik dalam kasus pembunuhan, bunuh diri, maupun kecelakaan serta dapat berasal dari seluruh tingkatan umur terutama di negara berkembang seperti Indonesia. ${ }^{2}$ Kekerasan adalah tindakan yang dilakukan secara disengaja dengan menggunakan kekuatan atau tindakan fisik, mekanik, ataupun kimia, yang bersifat mengancam baik diri sendiri maupun orang lain ${ }^{2}$

Afandi (2011) menemukan 613 kasus kematian tidak wajar dan hanya 73 kasus yang dilakukan autopsi medikolegal. Usia korban berkisar dari bayi baru lahir sampai 72 tahun, dengan rata-rata 28 tahun. ${ }^{2}$ Belum didapatkan data yang spesifik mengenai jumlah kasus kematian anak yang di autopsi di Provinsi Riau. Permintaan visum diajukan oleh pihak penyidik kepada Biddokkes Polda Riau sebagai sentral permintaan autopsi di Provinsi Riau sudah dilaksanakan sejak tahun 2007.

\section{METODE}

Penelitian ini merupakan penelitian deskriptif retrospektif dengan mengambil data Visum et Repertum (VeR) jenazah dengan korban yang berumur $<18$ tahun yang dilihat dari data identitas korban pada bagian pendahuluan. VeR yang diambil adalah VeR tertanggal Januari 2010 hingga Desember 2014. Data diambil di wilayah kerja Biddokkes Polda Riau sebagai sentral pelayanan penyelidikan di Provinsi Riau. Data yang dikumpulkan meliputi umur, jenis kelamin, jenis kekerasan, jenis luka, lokasi luka, jenis kasus, sebab mati, cara mati, mekanisme mati, dan asal polsek yang mengirimkan Surat Permintaan Visum (SPV). Data diolah dengan mengunakan komputer, kemudian ditampilkan dalam bentuk tabel dan grafik.

\section{HASIL DAN PEMBAHASAN}

Penelitian ini ditemukan 15 kasus korban anak yang diautopsi di wilayah kerja Biddokkes Polda Riau selama tahun 2010-2015. Karakterisrik korban berdasarkan angka kejadian per tahun diperlihatkan oleh gambar 1 .

Perbandingan antara jumlah total kasus autopsi forensik di Provinsi Riau dengan jumlah autopsi pada anak berbanding lurus. Gambar 1. didapatkan angka autopsi pada anak terus meningkat tiap tahunnya. Hal ini dikare- 
nakan adanya peningkatan pengurusan administrasi data VeR tiap tahunnya. Jika dibandingkan dengan penelitian yang dilakukan oleh Afandi pada periode sebelumnya, tidak terjadi peningkatan angka autopsi pada anak di Provinsi Riau $(n=15){ }^{2}$ Hal ini menunjukkan tidak ada peningkatan kesadaran masyarakat akan pentingnya pelaksanaan autopsi kasus kematian tidak wajar terutama pada kasus anak.

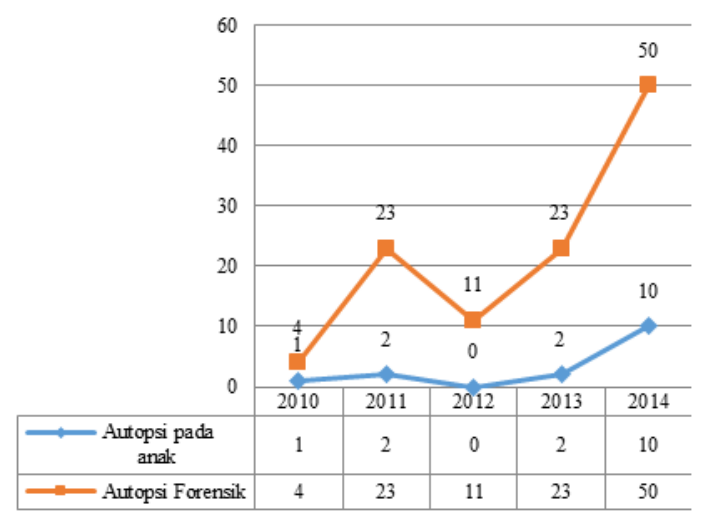

\section{Gambar 1. Jumlah Autopsi pada Anak di Provinsi Riau Periode Tahun 2010-2014}

Karakteristik korban anak yang diautopsi di Provinsi Riau periode 20102014 berdasarkan jenis kelamin dan usia. Berdasarkan tabel 1, didapatkan jenis kelamin korban anak diautopsi didominasi oleh laki-laki dengan jumlah 10 kasus $(66,7 \%)$. Hal ini sesuai dengan data dari penelitian yang di lakukan oleh Moustafa pada tahun 2013 di Mesir, bahwa dari 89 kasus anak yang diautopsi didapatkan 56 orang laki laki dan 33 orang perempuan. ${ }^{3}$ Hal ini didukung oleh teori yang mengatakan bahwa laki-laki memiliki Gen SRY (Sex Determining Region Y) dan hormon testosteron. Gen SRY mempengaruhi tingkat agresifitas dalam keadaan stress sehingga tingkat pengendalian emosi marah pada laki-laki lebih rendah dari pada perempuan. ${ }^{4}$ Hormon testosteron mempengaruhi perkembangan mental laki-laki dalam menghadapi masalah yaitu cenderung menyelesaikan dengan cara yang praktis dan rasional. ${ }^{4}$

Tabel 1. Karakteristik Korban Anak yang Diautopsi Berdasarkan Jenis Kelamin dan Usia

\begin{tabular}{cc}
\hline Karakteristik & Jumlah (\%) \\
\hline Jenis Kelamin & $5(33,3)$ \\
Perempuan & $10(66,7)$ \\
Laki-laki & \\
Usia (Tahun) & $7(46,7)$ \\
$0-5$ & $3(20)$ \\
$6-12$ & $5(33,3)$ \\
$13-18$ & \\
\hline
\end{tabular}

Berdasarkan karakteristik umur sebagaimana tergambar pada Tabel 1, umur korban anak terbanyak terdapat pada rentang usia 0-5 tahun yaitu sebanyak 7 orang (46,7\%). Hasil yang relatif sama pada penelitian yang dilakukan oleh Moustafa pada tahun 2013 di Mesir, didapatkan kelompok usia terbanyak pada bayi baru lahir $(41,6 \%) .^{3}$ Data dari Child Welfare Information Gateway 2015) menunjukkan bahwa anak-anak umur $<4$ tahun menjadi korban paling sering pada kematian anak akibat kekerasan. ${ }^{5}$

Berdasarkan gambar 2, dapat dilihat bahwa jenis kekerasan pada kasus autopsi pada anak yang paling sering adalah tidak tergolongkan yaitu sebanyak 7 kasus (46,7\%), diikuti dengan kekerasan tumpul sebanyak 5 kasus $(33,3 \%)$, sedangkan kekerasan tajam sebanyak 3 kasus (20\%). Jenis kekerasan pada korban anak tidak tergolongkan lebih banyak didapatkan, 
karena kemungkinan jenazah ditemukan dalam keadaan busuk atau merupakan kematian neonatal. Menurut Djaja (2003), dari kira-kira hampir delapan juta bayi yang meninggal setiap tahun, dua per tiga diantaranya terjadi pada masa neonatal (umur kurang dari satu bulan). ${ }^{6}$ Usia neonatal merupakan usia rentan terjadi pembunuhan anak sendiri (PAS), sebagaimana yang dilaporkan oleh Afandi (2008) bahwa hal tersebut dapat dikarenakan ibu yang takut ketahuan telah melahirkan seorang anak hasil hubungan gelap. ${ }^{7}$

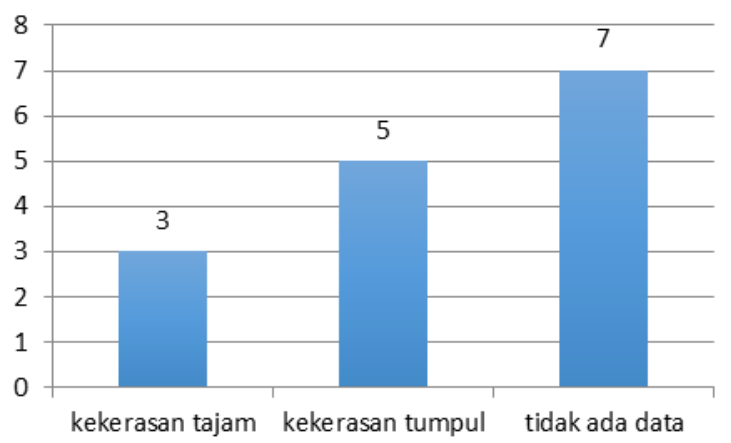

Gambar 2. Distribusi Jenis Kekerasan pada Korban Anak yang Diautopsi di Provinsi Riau Periode 2010-2014

Tabel 2. Karakteristik Korban Anak yang Diautopsi Berdasarkan Jenis Luka dan Jenis Kekerasan

\begin{tabular}{lccccccc}
\hline \multirow{2}{*}{ Jenis Kekerasan } & \multicolumn{3}{c}{ Luka Akibat Kekerasan } & \multicolumn{2}{c}{$\begin{array}{c}\text { Luka Akibat Kekerasan } \\
\text { Tajam }\end{array}$} & \multicolumn{3}{c}{\begin{tabular}{c} 
Tumpul \\
\cline { 2 - 7 }
\end{tabular}} & Bacok & Sayat & Tusuk & Memar & Lecet & Robek & \\
\hline Tajam & 0 & 2 & 0 & 0 & 2 & 2 & 6 \\
Tumpul & 0 & 1 & 0 & 3 & 1 & 1 & 6 \\
Tidak ada data & 0 & 0 & 0 & 0 & 0 & 0 & 0 \\
\hline
\end{tabular}

Luka akibat kekerasan tajam terdiri dari luka bacok, luka sayat, dan luka tusuk. Luka akibat kekerasan tumpul terdiri dari luka memar, luka lecet, dan luka robek. Tabel 2, dapat dilihat bahwa jenis luka tersering pada kekerasan tajam adalah luka sayat $(66,7 \%)$ dan jenis luka tersering pada kekerasan tumpul adalah luka memar (60\%). Luka sayat disebabkan oleh benda tajam yang ditekan dengan kekuatan relatif ringan kemudian digeserkan sepanjang kulit. ${ }^{8}$ Luka sayat dapat ditemukan pada kasus pembunuhan maupun bunuh diri.

Kasus pembunuhan yang disertai perlawanan, dimana luka sayat dapat ditemukan sebagai luka tangkis yang diakibatkan oleh gerakan menangkis untuk menghindari benda tajam yang diarahkan pada korban. ${ }^{9}$ Pada kasus bunuh diri, luka sayat dapat ditemukan sebagai luka percobaan. Hal ini yang merupakan luka khas pada kasus bunuh diri yang menggunakan benda tajam. Penelitian sebelumnya oleh Humsona (2004), dimana ia menyimpulkan bahwa penggunaan benda tajam merupakan salah satu cara yang ditempuh korban untuk melukai tubuhnya. ${ }^{10}$

Tabel 3 menunjukkan jenis luka akibat kekerasan tajam pada anak yang diautopsi, dimana lokasi terbanyak ditemukan pada leher. Hasil ini dapat disimpulkan bahwa lokasi leher menjadi 
target utama pelaku pada anak korban kekerasan tajam yang diautopsi di Provinsi Riau. Hal ini dikarenakan leher merupakan daerah paling terjangkau oleh tangan pelaku.

Tabel 3. Karakteristik Lokasi Luka Akibat Kekerasan Tajam pada Korban Anak yang Diautopsi.

\begin{tabular}{lc}
\hline \multicolumn{1}{c}{ Lokasi Luka } & Jumlah (\%) \\
\hline Leher & 3 Kasus \\
Ekstremitas Atas & 2 Kasus \\
Punggung & 1 Kasus \\
Ekstremitas Bawah & 1 Kasus \\
Kepala & 1 kasus \\
\hline
\end{tabular}

Lokasi luka akibat kekerasan tumpul pada korban anak yang diautopsi dapat dilihat pada tabel 4 . Jenis luka akibat kekerasan tumpul pada anak yang diautopsi paling banyak ditemukan di bagian kepala sebanyak 4 kasus. Hal ini dapat disimpulkan kepala merupakan lokasi vital dalam percobaan pembunuhan karena kekerasan tumpul.

Tabel 4. Karakteristik Lokasi Luka Akibat Kekerasan Tumpul pada Korban Anak yang Diautopsi

\begin{tabular}{ll}
\hline \multicolumn{1}{c}{ Lokasi Luka } & Jumlah \\
\hline Leher & 3 Kasus \\
Ekstremitas Atas & 1 Kasus \\
Kepala & 4 kasus \\
\hline
\end{tabular}

Autopsi medikolegal memiliki peran penting pada kasus kematian tidak wajar (unnatural deaths). Kematian akibat tindakan kriminal yang belum jelas penyebabnya disebut kematian tidak wajar. Autopsi medikolegal di Indonesia hanya dapat dilaksanakan apabila ada permintaan dari penyidik melalui SPV dan apabila penyebab kematian belum jelas dan masih belum dapat diterima baik oleh pihak korban maupun pihak tersangka sehingga membutuhkan adanya penyidikan. ${ }^{2}$

Berdasarkan tabel 5, digambarkan bahwa cara mati korban anak yang diautopsi di Provinsi Riau periode 20102014 seluruhnya adalah kematian tidak wajar. Hal ini sesuai dengan pendapat Afandi (2012), bahwa pembunuhan sebagai cara paling sering penyebab kematian korban. $^{2}$

Tabel 5. Distribusi Cara Mati Jenazah Anak yang Diautopsi

\begin{tabular}{lc}
\hline \multicolumn{1}{c}{ Cara Mati } & Jumlah (\%) \\
\hline Wajar & $0(0)$ \\
Tidak Wajar & $15(100)$ \\
\hline
\end{tabular}

Tabel 6, dapat dilihat bahwa kematian terbanyak disebabkan karena penyebab yang tidak dapat ditentukan. Hal ini terjadi karena minimnya bukti dan saksi dalam proses penyelidikan kasus sehingga sulit bagi dokter pemeriksa untuk menyimpulkan sebab kematian. Pembusukan mayat juga dapat menjadi masalah tidak didapatkannya penyebab kematian oleh karena keterbatasan jejak luka yang ada pada tubuh korban.

Tabel 6. Distribusi Kasus Kematian

\begin{tabular}{lc}
\hline \multicolumn{1}{c}{ Kasus } & Jumlah (\%) \\
\hline Pembunuhan & $9(60)$ \\
Bunuh Diri & $0(0)$ \\
Kecelakaan & $1(6,66)$ \\
Tidak Diketahui & $5(33,33)$ \\
\hline
\end{tabular}

Berdasarkan tabel 7, diperlihatkan sebab mati terbanyak pada kasus 
kematian jenazah anak yang diautopsi di Provinsi Riau periode 2010-2014 adalah sebab yang tidak dapat digolongkan $(33,3 \%)$. Sebab mati kedua dan ketiga terbanyak disebabkan oleh kekerasan tumpul $(26,7 \%)$ dan kekerasan tajam (20\%).

Tabel 7. Distribusi Sebab Mati Kasus Kematian Jenazah Anak yang Diautopsi di Provinsi Riau Periode 2010-2014

\begin{tabular}{lc}
\hline \multicolumn{1}{c}{ Sebab Mati } & Jumlah (\%) \\
\hline Kekerasan Tajam & $3(20)$ \\
Kekerasan Tumpul & $4(26,7)$ \\
Tajam dan Tumpul & $2(13,3)$ \\
Tenggelam & $1(6,7)$ \\
Tidak dapat Digolongkan & $5(33,3)$ \\
\hline
\end{tabular}

Berdasarkan mekanisme mati (tabel 8), sebanyak 46,7\% anak yang diautopsi tidak memiliki mekanisme mati yang jelas. Hal ini dikarenakan tidak ditemukannya penyebab kematian. Teori penentuan mekanisme mati sangat berhubungan dengan sebab mati korban tersebut. Sebab dari mati maupun mekanisme mati korban dapat tidak diketahui karena korban mati telah mengalami pembusukan, dimana dapat menyamarkan penyelidikan. Barang bukti dan saksi yang tidak cukup juga mempengaruhi untuk menyimpukan mengenai kasus kematian korban.

Permintaan VeR autopsi anak di Provinsi Riau seluruhnya berasal dari polsek asal luar daerah Pekanbaru. Distribusi daerah asal permintaan VeR dapat dilihat pada tabel 9.
Tabel 8. Distribusi Mekanisme Mati Korban Anak yang Diautopsi

\begin{tabular}{lc}
\hline \multicolumn{1}{c}{ Mekanisme mati } & Jumlah (\%) \\
\hline Pendarahan & $4(26,7)$ \\
Asfiksia & $4(26,7)$ \\
Tidak Diketahui & $7(46,7)$ \\
\hline
\end{tabular}

Tabel 9. Distribusi Asal Kepolisian yang Mengajukan SPV Autopsi Korban Anak

\begin{tabular}{lc}
\hline \multicolumn{1}{c}{ Kabupaten } & Jumlah (\%) \\
\hline Kabupaten Kampar & $6(40)$ \\
Kabupaten Siak & $3(20)$ \\
Kabupaten Dumai & $2(13,3)$ \\
Kabupaten Pelalawan & $2(13,3)$ \\
Kabupaten Rokan Hilir & $1(6,66)$ \\
Tidak Diketahui & $1(6,66)$ \\
\hline
\end{tabular}

Berdasarkan tabel 9, asal sektor luar Pekanbaru terdiri dari Kabupaten Kampar sebanyak 6 SPV (40\%), Kabupaten Siak sebanyak 3 SPV $(20 \%)$, Kota Dumai dan Kabupaten Pelalawan masing-masing sebanyak 2 SPV $(13,33 \%)$, dan diikuti dengan Kabupaten Rokan hilir sebanyak 1 SPV $(6,66 \%)$ dan 1 kasus berasal dari daerah tidak diketahui (6,66\%). Menurut Silitonga (2011) hal tersebut dikarenakan minimnya instansi di kabupaten luar Pekanbaru yang mampu mengeluarkan VeR melalui pelaksanaan autopsi medikolegal sehingga penyidik pada daerah tersebut meminta kepada instansi sentral Provinsi Riau yaitu Biddokkes Polda Riau untuk melakukan pemeriksaaan. ${ }^{11}$ 


\section{SIMPULAN}

Hasil penelitian didapatkan angka autopsi pada anak di Provinsi Riau periode tahun 2010-2014 berjumlah 15 kasus. Karakteristik korban anak didominasi anak laki-laki berumur 0-5 tahun. Penelitian ini didapatkan 5 kasus kekerasan tumpul, 3 kasus kekerasan tajam dan 7 kasus tidak dapat digolongkan jenis kekerasannya.

Jenis luka akibat kekerasan tajam didominasi oleh luka sayat

\section{DAFTAR RUJUKAN}

1. Budiyanto A, Widiatmaka W, Sudiono S, Mu'nim A, Winardi, Sidhi. IImu kedokteran forensik. Ed 1. Jakarta: Bagian Kedokteran Forensik Universitas Indonesia; 1997.

2. Afandi D. Profile of medicolegal autopsies in Pekanbaru, Indonesia 2007-2011. Malaysian J Patholog 2012;34(2):123-6.

3. Moustafa SM. Review of 89 autopsies of child deaths from violence and neglect in the Suez Canal area, Egypt. Departement of Forensic Medicine and Clinical Toxicology. Egypt Suez Canal University 2013.

4. Hardiyani T. Perbedaan pengendali-an emosi marah antara laki-Laki dan perempuan pada masa dewasa awal. Malang. Universitas Brawijaya 2009.

5. Child Welfare Information Gateway. Child abuse and neclect fatalities 2013: Statistics and interventions. Washington, DC: US. Departement of Health and Human services,. Children's Bureau 2015

6. Djaja S, Soemantri S. Penyebab kematian bayi baru Lahir (neonatal) dan sistem pelayanan kesehatan yang dengan lokasi luka tersering di leher sedangkan jenis luka akibat kekerasan tumpul didominasi oleh luka memar dengan lokasi luka tersering di kepala. Seluruh kasus merupakan kematian tidak wajar dengan kasus terbanyak adalah dugaan pembunuhan. Sebagian besar sebab mati dan mekanisme mati korban tidak dapat ditentukan. Seluruh SPV autopsi anak berasal dari luar Pekanbaru dengan Polsek Kabupaten Kampar yang merupakan asal polsek tersering.

berkaitan di Indonesia. Survei kesehatan rumah tangga (SKRT) 2001. Buletin Penelitian Kesehatan. 2003;31(3):155-65.

7. Afandi D, Atmadja DS, Widjaja IR. Pembunuhan anak sendiri dengan kekerasan multipel. MKI 2008;58(9): 355-9.

8. Erlando E, Johannis MF, Mallo NTS. Pola luka pada kematian akibat kekerasan tajam di Bagian IImu Kedokteran Forensik dan Mediko-legal RSUP Prof. Dr. R. D. Kandou Manado periode 2013. J Clin 2015 3(2):640-5.

9. Sheikh MI, Prajapati P, Kaushik P. Defense wounds in homicidal deaths. $J$ Indian Acad Forensic Med 31(1):18-21

10. Humsona R. Bunuh diri: faktor-faktor penyebab, cara yang ditempuh dan respons komunitas. $J$ Sosiolog 2004;17(1):59-66.

11. Silitonga, JAM. Profil korban perlukaan yang diperiksa di Rumah Sakit Bhayangkara tingkat IV Pekanbaru periode 1 Januari-31 Desember 2011. Skripsi. Pekanbaru Universitas Riau 2012. 